\title{
Multivariate statistical analysis in determining the enterprises' behavior with resources
}

\author{
Sergey Kravchenko, ${ }^{1,2,}$, and Mariia Pankova ${ }^{2}$ \\ ${ }^{1}$ Institute for International Cooperation Development, 24-26 Kazimierza Wielkiego Str, 61-863 \\ Poznan, Poland \\ ${ }^{2}$ Enterprise Economics Department, SHEE "Donetsk National Technical University", 2 Shybankova \\ Square, 85300 Pokrovsk, Donetsk region, Ukraine
}

\begin{abstract}
The threefold concept of sustainable development is largely based on the optimal use of limited resources. In this case, the development of an effective toolkit for the conscious influence of business entities to the effectiveness of using its resource base deserves special attention. The study attempts to substantiate the existence of several basic (characteristic) enterprises types in terms of resources usage results and to identify the key parameters that form a certain style of behavior. This approach includes the methods of multivariate statistical analysis (cluster and discriminant). The results obtained make it possible to assert the existence of four basic enterprises types with different styles of resource management, which affects the level of their resource security. Special attention was paid to identifying indicators that have the greatest separation power. In addition, the classification functions were built, and their quality was confirmed, which makes it possible to model the situation of targeted impact on individual indicators (forecasting the future situation for correction). The research results should contribute to an increase in the degree of the scientific validity recommendations for business entities on the rational use of their resource base (effective regulating the level of resource security).
\end{abstract}

\section{Introduction}

In modern aggravated competition conditions, the state of each enterprise largely depends on the nature of the resources' usage, that is, the ability to effectively use and develop its own resource base. At the same time, under the influence of numerous factors, the situation in all areas is constantly changing, objectively causing the need for various regulatory measures $[1,2]$.

One of the main regulation aspects of any process is the object's current state analysis, which allows identifying weaknesses, the reasons for their occurrence and the direction of the necessary impact (correction) [3-5]. Definitely, each enterprise, having a set of certain operating features, in the course of such an analysis will receive its own individualized

\footnotetext{
* Corresponding author: sergey.iv.kravchenko@gmail.com
} 
results. However, from a scientific point of view, general features and trends are of greater interest [6-73].

Given the above, to develop an effective toolkit for conscious influence on the effectiveness of using one's own resource base, the study made an attempt to substantiate the existence of several basic (generalized) enterprises' types based on their resources' management results, as well as to identify the key parameters that largely shape the style of behavior and thus, they are a priority for purposeful correction.

\section{Methods}

In the current study, the methods of multivariate statistical analysis (cluster and discriminant) were used: (1) cluster analysis - for dividing a certain set of enterprises into basic types; (2) discriminant analysis - for determining the variables with the greatest separation power and the formation of classification functions that can determine the enterprise's type by the nature of its behavior with resources.

The combination of these methods was carried out by using in the discriminant analysis as a dependent variable the enterprise's type, which was previously determined by cluster analysis, and as independent variables - 32 input indicators of personnel, financial, and production enterprise's subsystems.

\section{Results}

For the enterprises typologization (clustering) by the resource security level, the activities of 81 enterprises were analyzed, which belong to various sectors of the Ukrainian economy, are characterized by different sizes and functioning efficiency, as well as territorially located in different regions. For this purpose, three groups of indicators have been formed that characterize the financial condition, the level of personnel, material and technical security of their activities - that is, reflect the state and efficiency of the resources' main types use. In total, for the analysis 32 indicators, which represent the average value over the five years (before the COVID-19 coronavirus pandemic), were used.

The clustering of the study sample was performed by Ward's method of combining, which minimizes the intragroup variance for any two (hypothetical) clusters that can be formed at each step. The squared Euclidean distances were chosen as a measure of distance. Figure 1 shows the results of the hierarchical classification.

According to the data obtained, it is possible to distinguish from 4 to 6 clusters, which are not equal in objects number. After determining the number of possible clusters, the clustering algorithm, the k-means method, was implemented. The obtained results confirmed the feasibility of dividing the studied population into 4 clusters.

The first cluster included 8 enterprises, the second and the third -20 for each one's, the fourth cluster included 33 enterprises. Figure 2 shows the cluster centers in a standardized dimension for each type of enterprise.

Thus, it can be argued that there are four basic enterprises types with different resource management styles, which affect the level of their resource security.

Based on the standardized values of the five-year average of those indicators that have the greatest scope beyond the clusters, and their absolute values, the enterprises' distinctive features of each basic type are revealed. These features are the consequences of their different typical behavior in resource management:

Type 1 - predominantly high-profitable enterprises, with a large prevalence of current assets in the property structure and a low level of labor productivity; 


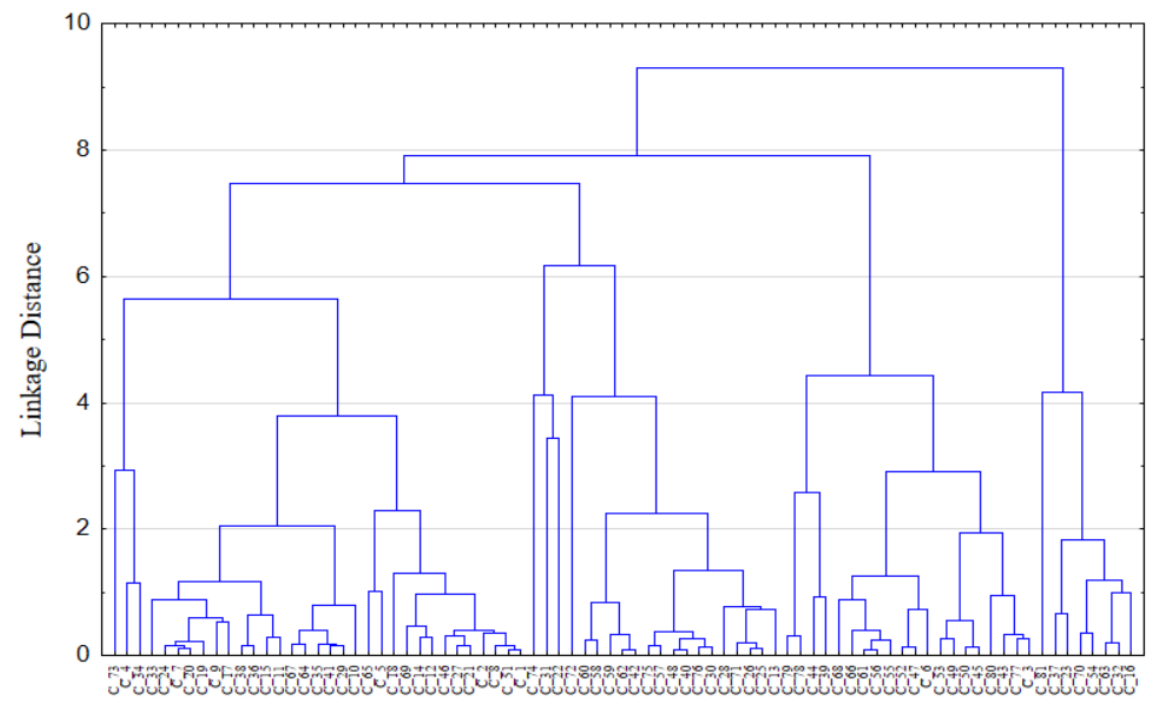

Fig. 1. The findings of the cluster analysis (hierarchical tree diagram for 81 cases).

Source: own computations.

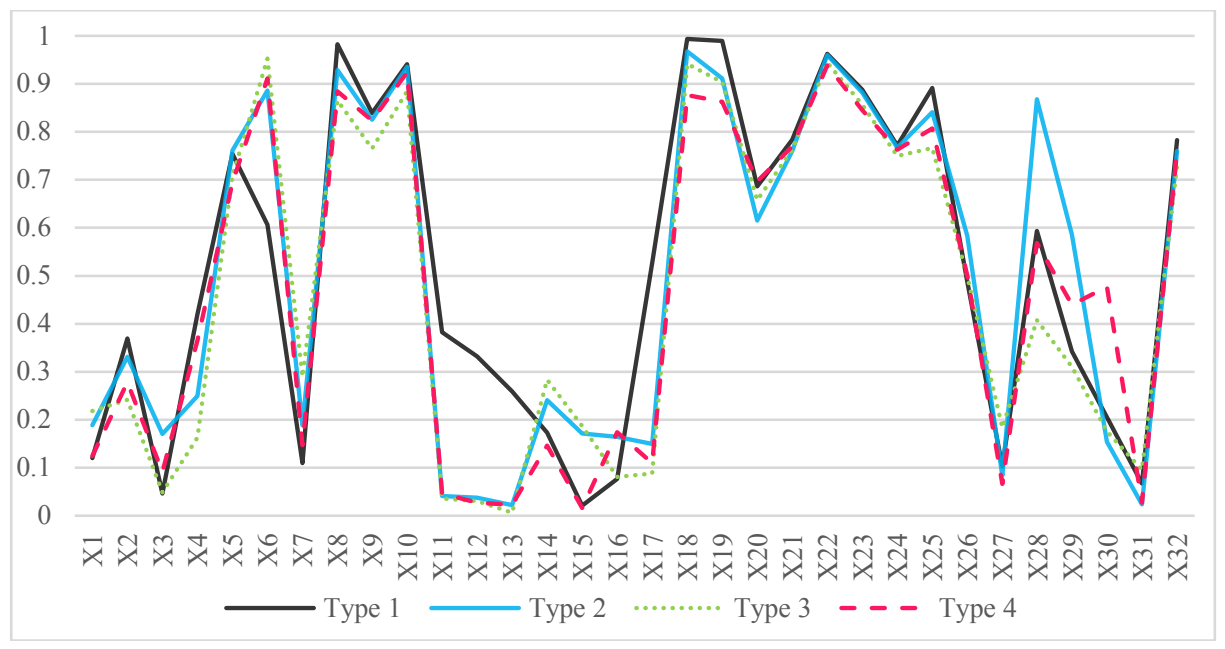

Note. "Personnel subsystem" ( $\mathrm{X}_{1}$ - Labor productivity, $\mathrm{X}_{2}$ - Average monthly wages, $\mathrm{X}_{3}$ - Fixed assets per worker, $\mathrm{X}_{4}-$ The share of wages in the production cost, $\mathrm{X}_{5}-$ Return on labor, $\mathrm{X}_{6}-$ The share of wages arrears in the debt capital, $\mathrm{X}_{7}-$ Wages to turnover ratio). "Financial subsystem" (X $\mathrm{X}_{8}-$ Equity ratio, $\mathrm{X}_{9}$ - Debt-to-equity ratio, $\mathrm{X}_{10}$ - Long-term debt to capitalization ratio, $\mathrm{X}_{11}$ - Asset coverage ratio, $\mathrm{X}_{12}$ - Quick ratio, $\mathrm{X}_{13}$ - Cash ratio, $\mathrm{X}_{14}$ - Assets turnover ratio, $\mathrm{X}_{15}$ - Inventory turnover ratio, $\mathrm{X}_{16}-$ Receivables turnover ratio, $\mathrm{X}_{17}$ - Accounts payable turnover ratio, $\mathrm{X}_{18}$ - Accounts payable and receivable ratio, $\mathrm{X}_{19}$ - Net working capital to current assets ratio, $\mathrm{X}_{20}$ - Working capital maneuverability ratio, $\mathrm{X}_{21}$ - Net working capital to equity ratio, $\mathrm{X}_{22}$ - Return on sales, $\mathrm{X}_{23}$ - Product profitability, $\mathrm{X}_{24}$ - Return on equity, $\mathrm{X}_{25}$ - Return on assets). "Production subsystem" ( $\mathrm{X}_{26}-$ Depreciation of fixed assets, $\mathrm{X}_{27}$ - Fixed assets turnover ratio, $\mathrm{X}_{28}$ - Material intensity of products, $\mathrm{X}_{29}$ - The share of fixed assets in assets, $X_{30}$ - The share of revolving production capital in current assets, $\mathrm{X}_{31}$ - Current and non-current assets ratio, $\mathrm{X}_{32}-$ Non-current assets to equity ratio).

Fig. 2. Cluster centers by standardized indicators.

Source: own computations. 
Type 2 - predominantly medium-profitable enterprises with equal shares of current and non-current assets and a high level of labor productivity;

Type 3 - predominantly medium-unprofitable enterprises with a large prevalence of current assets in the property structure and a high level of labor productivity;

Type 4 - predominantly high-unprofitable enterprises with a slight prevalence of current assets in the property structure and a low level of labor productivity.

According to study objectives, the next stage founds the variables that had the greatest impact on the distribution of enterprises by type. The tools of multiple discriminant analysis used for this purpose allow studying the differences between two or more groups of objects for several variables simultaneously.

The discriminant analysis is performed by the Forward stepwise method, according to which all variables are analyzed at each step, and the one that makes the greatest contribution to the difference between the populations is found. This variable is included in the model at this stage and the process proceeds to the next step. The procedure ends when all variables that have an F-value greater than indicated will include in the model $[74,75]$.

The nature of discrimination is investigated by canonical analysis, that is, the contribution of each discriminant function to the distribution between types of enterprises is determined. Table 1 provides information on the number of constructed discriminant functions (roots) and descriptive statistics indicating their information content.

Table 1. The findings of the discriminant analysis.

\begin{tabular}{|c|c|c|c|c|c|c|c|}
\hline $\begin{array}{c}\text { Roots } \\
\text { Removed }\end{array}$ & $\begin{array}{c}\text { Eigen- } \\
\text { value }\end{array}$ & $\begin{array}{c}\text { Canonical } \\
\text { correlation }\end{array}$ & $\begin{array}{c}\text { \% of } \\
\text { Variance }\end{array}$ & $\begin{array}{c}\text { Wilks' } \\
\text { Lambda }\end{array}$ & $\begin{array}{c}\text { Chi- } \\
\text { square }\end{array}$ & $\begin{array}{c}\text { Degrees of } \\
\text { freedom }\end{array}$ & p-level \\
\hline 1 & 4.02 & 0.90 & 45.00 & 0.02 & 271.52 & 60 & 0.00 \\
\hline 2 & 3.18 & 0.87 & 35.50 & 0.09 & 163.36 & 38 & 0.00 \\
\hline 3 & 1.74 & 0.80 & 19.50 & 0.37 & 67.56 & 18 & 0.00 \\
\hline
\end{tabular}

Source: own computations.

Table 1 shows that the first discriminant function explains $45.0 \%$ of the initial variability, the second $-35.5 \%$, the third $-19.5 \%$. Another characteristic that allows us to evaluate the utility of the discriminant function is the canonical correlation coefficient, the maximum value of which is one. The larger the value of the canonical $R$, the better the separation power of the discriminant function, that is, all constructed functions have high discriminant power. Tests of discriminant functions on the criteria of Wilks' Lambda, $\chi 2$-Pearson, and p-level confirmed their significance, that is, dividing the studied set of enterprises into four types is expedient.

The determination of the predictors that have the greatest value in the intergroup differences is based on a comparison of the absolute values of the standardized canonical discriminant function coefficients (Table 2).

Table 2 shows the standardized coefficients that indicate the relative importance of all 20 selected predictors in determining the enterprise's type for its resource management. The coefficients with the highest absolute values (highlighted in bold italics) are the variables with the greatest discriminatory power. In general, labor productivity has the greatest power (in terms of the absolute values amount -4.17), while the share of fixed assets in assets is the lowest one (0.48).

The obtained results confirm that the classification is correct, and the selected types of enterprises differ significantly from each other. Thus, using the selected most significant indicators, classification functions that have the following form were built: 


$$
D F=b_{1} x_{1}+\cdots+b_{i} x_{i}+\cdots+b_{p} x_{p}+C
$$

where $D F$ is discriminant function value; $x_{i}$ is the numerical value of the $\mathrm{i}$-th variable (predictor); $b_{i}$ is contribution of the $\mathrm{i}$-th variable to the function's value; $p$ is number of variables; $C$ is constant.

Table 2. Standardized canonical discriminant function coefficients.

\begin{tabular}{|c|c|c|c|c|}
\hline \multirow[b]{2}{*}{ Predictors } & \multicolumn{3}{|c|}{ Function } & \multirow{2}{*}{$\begin{array}{c}\text { The amount of the absolute } \\
\text { values of standardized } \\
\text { coefficients }\end{array}$} \\
\hline & 1 & 2 & 3 & \\
\hline Labor productivity & 1.23 & -2.08 & -0.86 & 4.17 \\
\hline Current and non-current assets ratio & -1.13 & 2.07 & 0.67 & 3.87 \\
\hline Product profitability & -0.86 & 1.57 & 1.32 & 3.75 \\
\hline Fixed assets turnover ratio & 1.18 & -1.81 & -0.49 & 3.48 \\
\hline Average monthly wages & -1.22 & 1.17 & 0.81 & 3.21 \\
\hline Wages to turnover ratio & -0.62 & 1.86 & 0.28 & 2.76 \\
\hline Return on sales & 0.81 & -0.91 & -0.96 & 2.69 \\
\hline Assets turnover ratio & -0.50 & 1.13 & 0.79 & 2.42 \\
\hline $\begin{array}{l}\text { The share of revolving production capital in } \\
\text { current assets }\end{array}$ & 0.43 & -0.57 & -0.74 & 1.74 \\
\hline Material intensity of products & -0.18 & 1.22 & -0.32 & 1.72 \\
\hline Return on assets & 0.08 & -0.79 & -0.67 & 1.54 \\
\hline Asset coverage ratio & -1.09 & -0.29 & -0.03 & 1.40 \\
\hline Accounts payable turnover ratio & -0.70 & 0.24 & -0.25 & 1.19 \\
\hline Cash ratio & 0.87 & 0.17 & 0.06 & 1.10 \\
\hline $\begin{array}{l}\text { The share of wages arrears in the debt } \\
\text { capital }\end{array}$ & -0.57 & -0.27 & -0.24 & 1.09 \\
\hline Equity ratio & 0.09 & 0.38 & 0.59 & 1.06 \\
\hline The share of wages in the production cost & -0.01 & 0.55 & -0.40 & 0.96 \\
\hline Long-term debt to capitalization ratio & -0.03 & 0.45 & 0.25 & 0.73 \\
\hline Depreciation of fixed assets & 0.05 & 0.43 & -0.24 & 0.73 \\
\hline The share of fixed assets in assets & -0.16 & -0.05 & 0.27 & 0.48 \\
\hline
\end{tabular}

Source: own computations.

In this case, the dependent variable is the type of enterprise, which was previously determined using cluster analysis, and the independent variables are 32 indicators of personnel, financial and production subsystems. Thus, for the four characteristic types of enterprises, the classification functions (based on the previously selected 20 predictors) will be as follows:

$$
\begin{aligned}
& \text { Type }_{1}=-137,007-0,047 x_{1}+9,345 x_{2}+86,853 x_{4}+80,984 x_{6}+7,444 x_{7}+7,407 x_{8}+1,267 x_{10}+ \\
& +3,191 x_{11}-8,212 x_{13}+29,022 x_{14}+1,553 x_{17}-0,661 x_{22}+0,639 x_{23}-0,63 x_{25}+34,337 x_{26}- \\
& -7,292 x_{27}+80,716 x_{28}+30,093 x_{29}-59,631 x_{30}+7,452 x_{31}
\end{aligned}
$$




$$
\begin{aligned}
& \text { Type }_{2}=-78,486-0,038 x_{1}+7,566 x_{2}+71,346 x_{4}-122,335 x_{6}+6,219 x_{7}+10,071 x_{8}+1,14 x_{10}+ \\
& +1,214 x_{11}-2,335 x_{13}+25,346 x_{14}+0,543 x_{17}-0,556 x_{22}+0,538 x_{23}-0,616 x_{25}+28,021 x_{26}- \\
& -5,511 x_{27}+56,294 x_{28}+30,06 x_{29}-45,601 x_{30}+5,816 x_{31} \\
& \text { Type }_{3}=-117,461-0,045 x_{1}+8,444 x_{2}+91,072 x_{4}-207,079 x_{6}+7,642 x_{7}+12,172 x_{8}+1,611 x_{10}+ \\
& +0,472 x_{11}-0,672 x_{13}+30,441 x_{14}+0,723 x_{17}-0,625 x_{22}+0,653 x_{23}-0,825 x_{25}+39,284 x_{26}- \\
& -6,913 x_{27}+89,2 x_{28}+26,561 x_{29}-57,016 x_{30}+7,325 x_{31} \\
& \text { Type }_{4}=-81,817-0,037 x_{1}+6,919 x_{2}+82,2 x_{4}-129,63 x_{6}+6,269 x_{7}+7,698 x_{8}+1,044 x_{10}+ \\
& +0,753 x_{11}-1,212 x_{13}+23,168 x_{14}+0,598 x_{17}-0,479 x_{22}+0,465 x_{23}-0,522 x_{25}+33,675 x_{26}- \\
& -5,372 x_{27}+67,486 x_{28}+24,856 x_{29}-27,201 x_{30}+5,643 x_{31}
\end{aligned}
$$

Company will belong to the type for which the calculated value will be the maximum.

It should be noted that the use of the obtained discriminant functions made it possible to correctly classify $96.3 \%$ of the analyzed enterprises (Table 3 ).

Table 3. Classification matrix.

\begin{tabular}{|c|c|c|c|c|c|}
\hline \multirow{2}{*}{$\begin{array}{c}\text { Observed } \\
\text { types }\end{array}$} & \multirow{2}{*}{$\begin{array}{c}\text { Percent } \\
\text { Correct }\end{array}$} & \multicolumn{4}{|c|}{ Predicted types } \\
\cline { 3 - 6 } & & Type 1 & Type 2 & Type 3 & Type 4 \\
\hline Type 1 & 100,0 & 8 & 0 & 0 & 0 \\
\hline Type 2 & 95,0 & 0 & 19 & 0 & 1 \\
\hline Type 3 & 95,0 & 0 & 1 & 19 & 0 \\
\hline Type 4 & 97,0 & 0 & 1 & 0 & 32 \\
\hline Total & 96,3 & 8 & 21 & 19 & 33 \\
\hline
\end{tabular}

A case is considered correctly classified if, according to the discriminant function, it is included in the group to which it actually belongs. In the study, the classification error is only $3.7 \%$, which indicates the high efficiency of the constructed tools.

The obtained classification functions can be used to identify the type of enterprises that were not involved in the study, and/or to make a forecast for future periods. Accordingly, it is also possible to implement a targeted impact on individual indicators to ensure the resource security of the enterprise.

\section{Conclusions}

In order to develop effective toolkit for the conscious influence of the enterprise to the effectiveness of using its own resource base in the study:

(1) four basic types of enterprises in terms of resource management, which can be used to analyze the individual characteristics of an individual business entity's behavior in the context of general and inter-cluster trends have been identified and described;

(2) the predictors that have the greatest separation power in terms of the enterprises' typology have been identified that makes it possible to prioritize adjustment measures the resource management style (the transition of an enterprise from one cluster to another);

(3) classification functions have been built and confirmed the its quality, based on which it becomes possible to carry out modeling of a targeted impact on individual indicators (forecasting a future situation for adjustment).

The multivariate statistical analysis considers individual variables as well as the interrelationships between them that allows obtaining more accurate information about the 
key regulatory parameters. The findings make it possible to improve the quality of management decisions to ensure resource security of business entities.

\section{References}

1. M.A.J. Parry, M.P. Reynolds, Annals of Applied Biology, 151(2), 133-135 (2007)

2. M. Gharfalkar, Z. Ali, G. Hillier, IJPPM, 67(9), 1854-1881 (2018)

3. Y. Kharazishvili, A. Kwilinski, O. Sukhodolina, H. Dzwigol, D. Bobro, J. Kotowicz, Energies, 14(8), 2126, (2021)

4. Y. Kharazishvili, A. Kwilinski, O. Grishnova, H. Dzwigol, Sustainability, 12(21), 8953 (2020)

5. Y. Kharazishvili, A. Kwilinski, H. Dzwigol, V. Liashenko, Virtual Economics, 4(2), 740 (2021)

6. O. Aleinikova, S. Kravchenko, V. Hurochkina, V. Zvonar, O. Brechko, Z. Buryk, JMIDS, 23(5), 564-576 (2020)

7. O. Burlaka, A. Kuzior, O. Hanych, S. Kravchenko, O. Melnychenko, JLERI, 22(2), 1-5 (2019)

8. V. Vostriakova, O. Kononova, S. Kravchenko, A. Ruzhytskyi, N. Sereda, IJCSNS, 21(3), 245-256 (2021)

9. A. Barzylovych, Y. Ursakii, A. Nadezhdenko, T.Mamatova, I. Chykarenko, S. Kravchenko, WSEAS Transactions on Environment and Development, 17, 619-629 (2021)

10. S. Cyfert, A. Chwiłkowska-Kubala, W. Szumowski, R. Miśkiewicz, PLoS ONE, 16(4), e0249724 (2021)

11. B. Czyżewski, A. Matuszczak, R. Miskiewicz, Technological and Economic Development of Economy, 25(1), 82-102 (2019)

12. H. Dzwigol, M. Dzwigol-Barosz, R. Miskiewicz, A. Kwilinski, Entrepreneurship and Sustainability Issues, 7(4), 2630-2644 (2020)

13. H. Dzwigol, M. Dzwigol-Barosz, Z. Zhyvko, R. Miskiewicz, H. Pushak, Journal of Security and Sustainability Issues, 8(3), 307-317 (2019)

14. E. Gross-Golacka, M. Kusterka-Jefmanska, R. Miskiewicz, B. Jefmanski, A. Rzepka, T. Kupczyk, European Research Studies Journal, XXIV(2B), 410-429 (2021)

15. L. Hrytsenko, I. Boiarko, O. Tverezovska, J. Polcyn, R. Miskiewicz, Marketing and Management of Innovations, 2, 155-165 (2021)

16. R. Miskiewicz, Polityka Energetyczna, 21(2), 49-62 (2018)

17. R. Miskiewicz, Virtual Economics, 2(2), 37-47 (2019)

18. R. Miskiewicz, Marketing and Management of Innovations, 3, 371-381 (2020)

19. R. Miskiewicz, Energies, 13(22), 6106 (2020)

20. R. Miśkiewicz, Journal of Risk and Financial Management, 14(2), 59 (2021)

21. R. Miśkiewicz, R. Wolniak, Sustainability, 12(14), 5776 (2020)

22. K. Pająk, O. Kvilinskyi, O. Fasiecka, R. Miskiewicz, Economics and Environment, 2(61), 122-138, (2017)

23. O. Prokopenko, R. Miskiewicz, Entrepreneurship and Sustainability Issues, 8(2), 269$284(2020)$ 
24. A. Rzepka, R. Borowiecki, R. Miskiewicz, Z. Olesinski, European Research Studies Journal, XXIV(2), 1149-1162 (2021)

25. P.W. Saługa, K. Szczepańska-Woszczyna, R. Miśkiewicz, M. Chłąd, Energies, 13(18), 4833 (2020)

26. H. Dźwigoł, Virtual Economics, 4(1), 98-117 (2021)

27. H. Dzwigol, M. Dźwigoł-Barosz, A. Kwilinski, International Journal of Entrepreneurship, 24(1), 1-5 (2020)

28. A. Kwilinski, O. Vyshnevskyi, H. Dzwigol, Journal of Risk and Financial Management, 13(7), 142 (2020)

29. O. Lyulyov, T. Pimonenko, A. Kwilinski, H. Dzwigol, M. Dzwigol-Barosz, V. Pavlyk, P. Barosz, Energies, 14(2), 373 (2021)

30. O. Lyulyov, I. Vakulenko, T. Pimonenko, A. Kwilinski, H. Dzwigol, M. DzwigolBarosz, Energies, 14(12), 3497 (2021)

31. A. Kwilinski, H. Dzwigol, V. Dementyev, International Journal of Entrepreneurship, 24(1 Special Issue), 1-5 (2020)

32. O. Arefieva, O. Polous, S. Arefiev, V. Tytykalo, A. Kwilinski, IOP Conference Series: Earth and Environmental Science, 628, 012039 (2021)

33. V. Boiko, A. Kwilinski, M. Misiuk, L. Boiko, Economic Annals-XXI, 175(1-2), 68-72 (2019)

34. S. Bogachov, A. Kwilinski, B. Miethlich, V. Bartosova, A. Gurnak, Entrepreneurship and Sustainability Issues, 8(2), 487-499 (2020)

35. O. Chygryn, Y. Bilan, A. Kwilinski, Marketing and Management of Innovations, 3, 356-368 (2020)

36. N. Dalevska, V. Khobta, A. Kwilinski, S. Kravchenko, Entrepreneurship and Sustainability Issues, 6(4), 1839-1860 (2019)

37. V.V. Dementyev, A. Kwilinski, Journal of Institutional Studies, 12(1), 100-116 (2020)

38. V. Koibichuk, N. Ostrovska, F. Kashiyeva, A. Kwilinski, Marketing and Management of Innovations, 1, 253-265 (2021)

39. V. Kondratenko, O. Okopnyk, L. Ziganto, A. Kwilinski, Marketing and Management of Innovations, 1, 87-94 (2020)

40. A. Kuzior, A. Kwilinski, V. Tkachenko, V. Entrepreneurship and Sustainability, 7(2), 1353-1376 (2019)

41. A. Kuzior, A. Kwilinski, I. Hroznyi, Energies, 14(9), 2572 (2021)

42. A. Kuzior, O. Lyulyov, T. Pimonenko, A. Kwilinski, D. Krawczyk, Sustainability, 13(15), 8145 (2021)

43. A. Kwilinski, Virtual Economics, 1(1), 7-25 (2018)

44. A. Kwilinski, Marketing and Management of Innovations, 4, 116-128 (2018)

45. A. Kwilinski, Academy of Accounting and Financial Studies Journal, 23(SI2), 1-6 (2019)

46. A. Kwilinski, V. Tkachenko, A. Kuzior, Journal of Security and Sustainability Issues, 9(2), 561-570 (2019)

47. A. Kwilinski, N. Dalevska, S. Kravchenko, I. Hroznyi, I. Kovalenko, Journal of Entrepreneurship Education, 22(SI1), 1-7 (2019)

48. A. Kwilinski, I. Ruzhytskyi, V. Patlachuk, O. Patlachuk, B. Kaminska, Journal of Legal, Ethical and Regulatory Issues, 22(SI2), 1-6 (2019) 
49. A. Kwilinski, R. Volynets, I. Berdnik, M. Holovko, P. Berzin, P. Journal of Legal, Ethical and Regulatory Issues, 22(SI2), 1-6 (2019)

50. A. Kwilinski, K. Pajak, O. Halachenko, S. Vasylchak, Y. Pushak, P. Kuzior, Marketing and Management of Innovations, 4, 172-181 (2019)

51. A. Kwilinski, A. Kuzior, Management Systems in Production Engineering, 28(2), 119123 (2020)

52. A. Kwilinski, Y. Zaloznova, N. Trushkina, N. Rynkevych, E3S Web of Conferences, 168, $00031(2020)$

53. A. Kwilinski, M. Dielini, O. Mazuryk, V. Filippov, V. Kitseliuk, Journal of Security and Sustainability Issues, 10(1), 345-358 (2020)

54. A. Kwilinski, D. Shteingauz, V. Maslov, Financial and Credit Activities: Problems of Theory and Practice, 3(34), 133-140 (2020)

55. A. Kwilinski, I. Slatvitskaya, T. Dugar, L. Khodakivska, B. Derevyanko, International Journal of Entrepreneurship, 24(1 Special Issue), 1-8 (2020)

56. A. Kwilinski, V. Litvin, E. Kamchatova, J. Polusmiak, D. Mironova, International Journal of Entrepreneurship, 25(1), 1-8 (2021)

57. Y. Kyrylov, V. Hranovska, V. Boiko, A. Kwilinski, L. Boiko, L. Journal of Risk and Financial Management, 13(12), 303 (2020)

58. V. Lakhno, V. Malyukov, T. Bochulia, Z. Hipters, A. Kwilinski, O. Tomashevska, International Journal of Civil Engineering and Technology, 9(8), 1802-1812 (2018)

59. O. Lyulyov, T. Pimonenko, A. Kwilinski, Y. Us, E3S Web of Conferences, 250, 03006 (2021)

60. K. Pająk, B. Kamińska, O. Kvilinskyi, O. Financial and Credit Activity: Problems of Theory and Practice, 2(21), 204-217 (2016)

61. T. Savchenko, N. Basiurkina, O. Rodina, A. Kwilinski, Management Theory and Studies for Rural Business and Infrastructure Development, 41(1), 43-61 (2019)

62. V. Tkachenko, A. Kwilinski, O. Korystin, N. Svyrydiuk, I. Tkachenko, Journal of Security and Sustainability, 8(3), 375-385 (2019)

63. V. Tkachenko, A. Kwilinski, M. Klymchuk, I. Tkachenko, Management Systems in Production Engineering, 27(2), 119-123 (2019)

64. V. Tkachenko, A. Kwilinski, I. Tkachenko, P. Puzyrova, Marketing and Management of Innovations, 2, 228-238 (2019)

65. V. Tkachenko, A. Kwilinski, B. Kaminska, I. Tkachenko, P. Puzyrova, Financial and Credit Activity: Problems of Theory and Practice, 3(30), 85-94 (2019)

66. V. Tkachenko, A. Kuzior, A. Kwilinski, Journal of Entrepreneurship Education, 22(6), 1-10 (2019)

67. L.M. Karpenko, M. Serbov, A. Kwilinski, V. Makedon, S. Drobyazko, Academy of Strategic Management Journal, 17(5), 1-7 (2018)

68. M. Borychowski, S. Stępień, J. Polcyn, A. Tošović-Stevanović, D. Ćalović, G. Lalić, M. Žuža, Sustainability, 12(24), 10362 (2020)

69. B. Czyżewski, A. Matuszczak, J. Polcyn, K. Smędzik-Ambroży, J. Staniszewski, Journal of Cleaner Production, 260, 121064 (2020)

70. J. Polcyn, Management, 22(2), 171-186 (2018)

71. J. Polcyn, Sustainability, 13(15), 6846 (2021) 
72. A. Zielińska-Chmielewska, A. Olszańska, J. Kaźmierczyk, E.V. Andrianova, Agronomy, 11(2), 299 (2021)

73. R. Abazov, Herald of Journalism, 58(4), 34-43 (2021)

74. N. Bureeva, Multivariate statistical analysis using "STATISTICA" (Nizhny Novgorod, 2007)

75. K. Kocisova, M. Misankova, Discriminant analysis as a tool for forecasting company's financial health, in Proceedings of the 2-dn International Scientific conference "Contemporary Issues in Business, Management and Education 2013", 110, 1148-1157 (2014) 